\title{
Response differences stability model simplify the identification of stable rice genotypes for low temperature environment
}

\author{
Bal Krishna Joshi \\ National Agriculture Genetic Resource Centre, Khumaltar, Lalitpur \\ Email: joshibalak@yahoo.com
}

\begin{abstract}
Stable genotype is necessary for long-term grain security to the farmers. Developing sitespecific variety is a good way of maintaining diversity and getting potential yield. Simple parameters were estimated based on nine rice genotypes evaluated under low temperature at three different altitudinal environments of Jumla, Lumle and Khumaltar. The genotypes were influenced by the varying conditions and $G \times E$ interaction which was highly significant for maturity, bearing tiller, and plant height and grain yield indicating responses of the rice genotype in different environments. These traits are very important for adoption of genotypes in farmers' field. It can be inferred that there is a possibility of developing site-specific variety which are stable and adoptable across these environments. Cold environment rice genotypes of NR10288-015J-15J-7, Chhommrong and NR10293 are most stable and ideally adapted in cold stress environment. NR 10346 is the site-specific genotype adapted to favorable environments. Hence, these genotypes could be used in breeding programs for increasing the productivity of rice in cold environment and for general cultivation as well.
\end{abstract}

Key words: low temperature, REDIS, rice genotype, response difference stability

\section{Introduction}

Nepal is a mountainous country with a great diversity of rice ecosystem. Rice is grown in all agro-ecological zones ranging from Tarai (Jhapa, $60 \mathrm{~m}$ ) to the high mountains (Chumchaur, Jumla 3050 m) (Mallick 198/82). There are many landraces suited to diverse agroclimate and farmers' needs (Joshi 2004).

A stable genotype is needed for increasing commercial cultivation over a wide range of agroclimatic conditions on mid and high hills of Nepal. Diverse genotypes are necessary to cope adverse environments. Diversity of 20 released rice cultivars was studied by Joshi (2006). Stable genotype across environment and site-specific genotypes are the ultimate objectives of rice breeding program. The occurrence of a large genotype $\mathrm{x}$ environment $(\mathrm{GxE})$ interaction poses major problem of relating phenotype performance to genetic constitution and make its difficult to decide which genotype should be selected. It is important to understand the nature of GE interaction to make testing and ultimately selection of genotypes more efficient. Bilbro and Ray (1976) mentioned that the use of the two parameters, adaptation and stability, in conjunction with yield would be of 
signification benefit in the evaluation and characterization of breeding materials. Joshi et al (2003) has selected NR 10414-38 as stable genotype and NR 10342 and NR 10353 as genotypes adapted for favorable environments. Here we have used simple method to select stable and adaptable genotypes to include in next year's experiment.

Between the two biplot techniques, i.e., additive main effect and multiplicative interaction (AMMI) (Zobel et al; 1988; Shafii, 1992), and genotype and genotype $\times$ environment interaction (GGE biplot) (Yan et al; 2000), GGE biplot has been reported to be better for genotype evaluation (Yan et al; 2007).

\section{Materials and methods}

Agriculture Botany Division (ABD), Khumaltar developed segregating lines of rice genotypes regularly and advanced them. A total of 12 rice genotypes were tested (Table 1) in 2001. Some of these lines were developed by ABD, and some were introduced from International Rice Research Institution (IRRI), Philippines. One released cultivars, Chrommrong and one local landrace, Jumli Marshi were included in this exterminate as check cultivars. Three lines were not germinated in Khumaltar and heavily infested by blast in Jumla therefore; these lines (LR96006, Lumle-2 and Lumle-5-1-1) were excluded from analysis.

This study was conducted in three different locations, Agriculture Research Station, Bijayanagar, Jumla; Agriculture Research Station, Bhakimle, Lumle and Agriculture Botany Division, Khumaltar, Lalitpur. These stations, Jumla, Lumle and Khumaltar are located at an elevation of 2423, 1800 and $1350 \mathrm{~m}$ respectively. Some genotypes were selected from Advance Nursery of ABD and some from Temperate Observation Nursery of IRRI, Philippines.

\section{Table 1. Rice genotypes used in the study with their pedigree}

\begin{tabular}{|c|c|c|c|c|c|}
\hline SN & Genotype & Abb & Pedigree & Sources $\uparrow$ & Remarks \\
\hline 1 & Chhommrong & Chhommrong & Ghandruk local & ARS, Lumle & $\begin{array}{l}\text { Cold tolerance used as a check, } \\
\text { released in } 1991\end{array}$ \\
\hline 2 & Fuji-102 / Jumli Marshi & Fuji/JM & - & ABD, Khumaltar & Crossed in 1990 \\
\hline 3 & Jinling-78 & Jinling-78 & Jinling-78-102 & IRRI, Philippines & $\begin{array}{l}\text { Cold tolerance, introduced in } \\
1995\end{array}$ \\
\hline 4 & Jumli Marshi & $\mathrm{JM}$ & - & ARS, Jumla & $\begin{array}{l}\text { Cold tolerance, popular local } \\
\text { landrace, blast susceptible }\end{array}$ \\
\hline 5 & LR 96006 & - & - & ARS, Lumle & - \\
\hline 6 & Lumle-2 & - & - & ARS, Lumle & - \\
\hline 7 & Lumle-5-1-1 & - & - & ARS, Lumle & - \\
\hline 8 & NR10288-015J-015J-7 & NR10288-015J & Akiyudaka / Jumli Marshi & ABD, Khumaltar & Crossed in 1989 \\
\hline 9 & NR10288-15J-15J-1 & NR10288-15J & Akiyudaka / Jumli Marshi & ABD, Khumaltar & Crossed in 1989 \\
\hline 10 & NR10293-015J-015J-8 & NR10293 & K333 /Jumli Marshi & ABD, Khumaltar & Crossed in 1989 \\
\hline 11 & NR10346-4-1-3 & NR10346 & Fuji-102 /Barkat & ABD, Khumaltar & Crossed in 1992 \\
\hline 12 & Yunlen-1 & Yunlen-1 & Yunlen-1 & IRRI, Philippines & $\begin{array}{l}\text { Cold tolerance, introduced in } \\
1995\end{array}$ \\
\hline
\end{tabular}

† ARS, Agriculture Research Station. ABD, Agriculture Botany Division. IRRI, International Rice Research Institute. 
The experiment was laid out with three replications in randomized complete block design. Plot size was 2- x 3- m. Nursery to raise the seedlings was established as per the appropriate time of respective site. In Lumle experiment treatment was replicated twice. Treatment response on third replication was estimated using MSTAT software. This was done to make equal replication in all sites. Seedling of 25-30 days old was transplanted at the spacing of 20- x $15-\mathrm{cm}$. Two seedlings per hill were followed in all sites. Fertilizers were applied @ of 80:30:30 kg NPK per ha. Full dose of P and K along with half dose of $\mathrm{N}$ was applied as basal dose at transplanting. Remaining half dose of $\mathrm{N}$ was top-dressed into two splits doses, one at 25 days after transplanting and another at 45 days after transplanting. All others recommended agronomical practices were followed. The data were recorded on grain yield, 1000-grain weight, effective tillers, plant height and date of maturity. These traits were measured as described by Joshi (2003a).

Analysis of variance (AOV) was conducted for each site data according to procedure outline by Gomez and Gomez (1886) and Joshi et al (2000). The environment-wise AOV indicated the genotype effects of significant at all site. After testing the homogeneity of variance, data were subjected to stability analysis. There are many methods for selecting stable and well-adopted genotype eg Finley and Wilkinson (1963) model, Eberhart and Russell (1966) etc. Most of these stability models are difficult to apply especially to estimate stability and adoptability parameters. These are also better suited to those experiment conducted in more than 2 environments. Joshi et al (2003) has used Finley and Wilkinson (1963) model to select rice genotypes. Here we have used very simple called Response Differences Stability (REDIS) model to select stable genotypes and well adopted genotypes to specific site. With this model, we can select suitable genotypes for further experimenting even from the experiment conducted in two environments. In this model, all possible pair-wise differences are calculated. The sing of these value getting from subtraction are ignored. Values are now used to estimate average (here called AvD, Average of Differences) and standard deviation (here called SDD, Standard Deviation of Differences). AvD and SDD are the stability and adaptability parameters. The genotype with lowest AvD and SDD are called stable and adopted to all environments. Standard deviation (SD) of original data is also calculated from original data and used in REDIS model. We can equally use this model on non-replicated data with multi environment data. Cultivars with highest AvD, SDD and SD are defined as well adapted to favorable environment. This model may be suitable for preliminary screening the genotypes tested in multi environments. Data analysis was done in Excel program. 


\section{Results and discussion}

Rice genotypes were highly significantly different among them in all sites, Jumla, Lumle and Khumaltar for four traits ie days to maturity plant height, panicle number and grain yield. Variation exists between these genotypes within and between sites. Results of combined analysis of variance are given in Table 2. Combined analysis indicated that there were highly significant different between sites, between genotypes and their interaction effects. This Table guided for selecting stable genotypes across sites and most adopted genotype in favorable environment. Option exists to select better genotypes based on days to maturity, plant height, panicle number and grain yield. These traits are considered most important by farmers.

Responses of these genotypes in each site and site mean are given in Table 3a and 3b. As the altitude of experimental site increase the days to maturity is also increased. Direct relationship between altitude and maturity period exists. Most probably this is due to variation in temperature. Earliest genotype, NR 10293 was matured in 126 days in Khumaltar and most long duration genotype was matured within 197 days in Jumla. In all these sites farmers prefer short duration genotypes. Relatively farmers in Jumla are more sensitive to maturity period than others. This is because of matching cropping sequences before snowfall. Chaitra 12 is the day of rice seeding for all Jumli farmers. This traditional system needs to verify scientifically. In the hilly area, the rice crop gets exposed to low temperature at flowering phase, and causes poor panicle exertion, asynchronous flowering, spikelets sterility and poor grain filling which ultimately result in yield reduction. If we can seed earlier, cropping intensity in Jumla can be increased and help to be self sufficient for food. Altitudinal effect is also noticed on plant height. All genotypes were shorter in height grown in Jumla than those grown in Khumaltar and Lumle. All these genotypes were tallest grown in Lumle. Jinling-78 was shortest and Jumli Marshi was tallest genotypes grown in Jumla and Lumle respectively. Plant height is important both in term of lodging susceptibility and use value to farmers. Systematic changes in plant height were observed among sites. It indicated that climatic variation is more influential to change height in these genotypes.

Highest panicle number was observed in all genotypes except NR 10288-15 grown in Lumle site. Similarly genotypes grown in Jumla produced lowest panicle number. Response pattern of these genotypes with respect to environment was similar to plant height. Jumli Marshi produced highest panicle number grown in Lumle and Yenlen-1 produced lowest grown in Jumla. Panicle number is direct responsible to increase yield and straw in rice (Joshi 2003b). Geographic pattern as observed in days to maturity, plant height and panicle number was not existed in grain yield. Probably this happened because of polygenic effect on grain yield. NR10346 produced highest grain yield grown in Lumle. Lowest grain was produced by NR10288-15J grown in Khumaltar. No genotypes have 
produced greater grain yield grown in Khumaltar than those grown in Jumla and Lumle. This may be due to cold tolerance genes available in these genotypes, which are not suitable to Khumaltar condition. It indicates that Lumle and Jumla are good locations for screening genotypes of cold tolerance. To match the temperature of Khumaltar with the temperature of Lumle and Jumla, rice are planted late in Khumaltar to select cold tolerance genotypes. Jumli Marshi, a popular local landrace in Jumla produced more yield in other location than in Jumla. This possibility exists to increase yield by relocating the landraces in more or less similar environments. If farmers could get the yield whatever these genotypes have produced in this experiment especially in Jumla, this will be great achievement to make Jumla as food sufficient district.

The simple parameters, AvD, SDD and SD were used to select stable and site-specific genotypes that can be again included in the experiments (Table 4). Chhommrong, NR10288-015J and NR10288-15J have lower AvD, SDD and SD therefore these are grouped as stable genotypes with respect to yield response. The genotype with highest AvD, SDD and SD is NR10346 and this genotype is highly adapted to favorable environments. NR10293 is stable for days to maturity. Chhommrong and NR10346 are stable for plant height and NR10288-15J is stable to panicle number. Stability of these genotypes differed with respect to traits. Even though we selected genotypes considering only grain yield.

REDIS is simple method of selecting genotypes for their stability and adaptability. Climatic data should also be related in such study for getting effective conclusions. Great variation among genotypes across locations indicted the right choice of genotypes included in this experiment. Site specific and stable variety can be developed from these genotypes. Most of these genotypes did better in all studied traits than check varieties. Result indicated Lumle as a good site for expressing these traits. All these genotypes performed better in cooler area. Three genotypes NR10288-015J, NR10288-15J and NR 10346 can be used in further experiment. For drawing better conclusions these genotypes should be tested over years in these locations.

Table 2. Combined analysis of variance for different traits of nine rice genotypes

\begin{tabular}{|c|c|c|c|c|c|c|c|c|c|}
\hline \multirow[t]{2}{*}{ Sources } & \multirow[t]{2}{*}{ df } & \multicolumn{2}{|c|}{$\begin{array}{l}\text { Days } \\
\text { maturity }\end{array}$} & \multicolumn{2}{|c|}{ to Plant height } & \multicolumn{2}{|c|}{ Panicle number } & \multicolumn{2}{|l|}{ Grain yield } \\
\hline & & MS & $\mathrm{P}$ & MS & $\mathrm{P}$ & MS & $\mathrm{P}$ & MS & $\mathrm{P}$ \\
\hline Sites (S) & 2 & 4459.4 & 0.00 & 12724.0 & 0.00 & 73188.5 & 0.00 & 267116690 & 0.00 \\
\hline Replication within S & 5 & 3.35 & & 40.3 & & 2208.5 & & 666234 & \\
\hline Genotypes (G) & 8 & 172.6 & 0.00 & 986.7 & 0.00 & 2488.7 & 0.002 & 8850371 & 0.00 \\
\hline $\mathrm{S} \times \mathrm{G}$ & 16 & 83.25 & 0.00 & 142.2 & 0.00 & 2547.8 & 0.00 & 4933295 & 0.00 \\
\hline Error & 40 & 3.01 & & 11.8 & & 645.1 & & 366878 & \\
\hline
\end{tabular}


Table 3a. Days to maturity and plant height of nine rice genotypes in tested sties $\uparrow$

\begin{tabular}{llllllllll}
\hline SN & Genotype & Days to maturity & \multicolumn{7}{c}{ Plant height, cm } \\
\hline & & Jumla & Lumle & Khumaltar & Mean & Jumla & Lumle & Khumaltar & Mean \\
\hline 1 & Chhommrong & 197 & 158 & 132 & 162 & 75.43 & 107 & 102.5 & 94.98 \\
2 & Fuji/ JM & 197 & 158 & 128 & 161 & 78.77 & 103.67 & 102.17 & 94.87 \\
3 & Jinling-78 & 197 & 158 & 128 & 161 & 61.03 & 130.67 & 102.5 & 98.07 \\
4 & Jumli Marshi & 186 & 158 & 128 & 158 & 83.4 & 135.67 & 123 & 114.02 \\
5 & NR10288-015J & 197 & 158 & 128 & 161 & 67.26 & 125.67 & 103.25 & 98.73 \\
6 & NR10288-15J & 189 & 137 & 134 & 153 & 67.07 & 113 & 103.25 & 94.44 \\
7 & NR10293 & 189 & 131 & 126 & 149 & 75.4 & 124 & 103.75 & 101.05 \\
8 & NR10346 & 197 & 158 & 129 & 161 & 60.8 & 88 & 82.67 & 77.16 \\
9 & Yunlen-1 & 197 & 158 & 125 & 160 & 86.77 & 134 & 125 & 115.26 \\
& Mean & 194 & 153 & 129 & 158 & 64.50 & 117.96 & 105.34 & 95.94 \\
& CV, \% & 1.1 & 2 & 1 & & 5.7 & 3.8 & 1.4 & 2.63 \\
\end{tabular}

$\uparrow$ See Table 1 for genotypes details. CV, Coefficient of variance, LSD, least significance difference

Table 3b. Panicle number and grain yield of rice genotypes tested in tested sties

\begin{tabular}{llllllllll}
\hline SN & Genotype & \multicolumn{2}{l}{ Panicle/sqm, n } & \multicolumn{5}{c}{ Grain yield, kg/ha } \\
\hline & & Jumla & Lumle & Khumaltar & Mean & Jumla & Lumle & Khumaltar & Mean \\
\hline 1 & Chhommrong & 225 & 317 & 292 & 278 & 4495 & 2827 & 3991 & 3771.00 \\
2 & Fuji / JM & 248 & 333 & 309 & 297 & 3984 & 5143 & 2353 & 3826.67 \\
3 & Jinling-78 & 255 & 350 & 341 & 315 & 5410 & 5637 & 2643 & 4563.33 \\
4 & Jumli Marshi & 236 & 417 & 222 & 292 & 2279 & 4026 & 910 & 2405.00 \\
5 & NR10288-015J & 235 & 350 & 314 & 300 & 3917.7 & 2254 & 3758 & 3309.90 \\
6 & NR10288-15J & 262 & 283 & 285 & 277 & 4458 & 2689.8 & 831 & 2659.60 \\
7 & NR10293 & 267 & 333 & 284 & 295 & 4130 & 2273 & 2169 & 2857.33 \\
8 & NR10346 & 241 & 400 & 317 & 319 & 3623 & 8528 & 2660 & 4937.00 \\
9 & Yunlen-1 & 202 & 383 & 369 & 318 & 5557 & 7237 & 3929 & 5574.33 \\
& Mean & 241 & 352 & 304 & 299 & 4205.96 & 4512.75 & 2582.66 & 3767.13 \\
& CV \% & 8.9 & 9.9 & 7.4 & & 8 & 27.4 & 7.7 & \\
& LSD (5\%) & 37.01 & 65.76 & 40.43 & & 587.4 & 2325.7 & 342.4 & \\
\hline
\end{tabular}

Table 4. Mean and standard deviation of differences of response variables among sites for selecting stable genotypes

\begin{tabular}{llllllllllllll}
\hline SN & Genotype & \multicolumn{3}{c}{ Days to maturity $\dagger$} & \multicolumn{3}{c}{ Plant height } & \multicolumn{4}{c}{ Panicle number } & \multicolumn{3}{c}{ Grain yield } \\
\cline { 3 - 13 } & & AvD & SDD & SD & AvD & SDD & SD & AvD & SDD & SD & AvD & SDD & SD \\
\hline 1 & Chhommrong & 43.33 & 19.81 & 28.33 & 21.38 & 14.47 & 16.18 & 60.89 & 35.15 & 58.48 & 1112.46 & 643.59 & 1728.84 \\
2 & Fuji/ JM & 39.11 & 26.73 & 27.46 & 16.49 & 13.22 & 12.15 & 56.67 & 33.40 & 56.97 & 1860.00 & 887.43 & 1722.00 \\
3 & Jinling-78 & 40.44 & 30.13 & 29.01 & 46.31 & 21.30 & 30.36 & 64.66 & 44.95 & 54.27 & 2381.94 & 1319.46 & 1604.94 \\
4 & Jumli Marshi & 38.67 & 16.84 & 25.14 & 34.73 & 20.26 & 23.66 & 120.22 & 56.49 & 72.90 & 2077.62 & 922.60 & 1603.29 \\
5 & NR10288-015J & 40.44 & 20.51 & 26.87 & 38.82 & 18.61 & 25.60 & 76.44 & 44.46 & 64.95 & 1109.25 & 828.55 & 2192.29 \\
6 & NR10288-15J & 36.89 & 29.55 & 27.04 & 30.62 & 18.92 & 21.10 & 35.48 & 19.61 & 53.25 & 2101.43 & 1840.44 & 1382.26 \\
7 & NR10293 & 42.22 & 32.06 & 30.43 & 32.40 & 14.60 & 21.21 & 48.66 & 27.11 & 65.45 & 1037.32 & 1302.62 & 1484.13 \\
8 & NR10346 & 45.78 & 21.93 & 30.13 & 18.13 & 11.58 & 12.94 & 109.85 & 72.37 & 60.13 & 2474.34 & 3632.97 & 1950.53 \\
9 & Yunlen-1 & 44.67 & 25.87 & 30.26 & 31.49 & 20.12 & 21.82 & 120.67 & 92.83 & 63.33 & 2205.31 & 996.60 & 1219.34 \\
\hline
\end{tabular}

$\dagger$ AvD, Average of differences among sites. SDD, Standard deviation of differences among sites. SD, Standard deviation of original data.

\section{Acknowledgements}

Ashok Mudwari for support to execute the experiment and DMS Dongol for computer support works. 


\section{References}

Bilbro, JD and LL Ray. 1976. Environmental stability and adaptation of several cotton cultivars. Crop Sci. 16:821-824.

Eberhart, SA and WA Russel. 1966. Stability parameters for comparing varieties. Crop Sci. 6:36-40.

Finley, KW and GN Wilkinson. 1963. The analysis of adaptation in plant breeding program. Aust. J. Agric. Res. 14:742-754.

Gomez, KA and AA Gomez. 1984. Statistical procedures for agricultural research. $2^{\text {nd }}$ edition. John Wiley and Sons, New York.

Joshi, BK; KP Shrestha; and S Bista. 2003. Yield stability analysis of promising rice genotypes in mid hills of Nepal. In: Rice research report. HK Shrestha, B Chaudhary, EM Bhattrai and T Aktar, eds. Proceedings of 23rd National Summer Crops Research Workshop, 2-4 July 2002, Kathmandu, NARC. Pp. 109-116.

Joshi, BK; S Gyawali; and D Poudyal. 2002. Regression analyses and multiple comparison procedures: Uses and misuses. JIST. 12:69-81.

Joshi, BK. 2004. Rice gene pool for mid and high hills and its conservation in Nepal. In: Agricultural Research for Enhancing Livelihood of Nepalese People (BK Joshi, SL Joshi and KP Paudyal, eds). Proceedings of $2^{\text {nd }}$ SAS-N Convention, 30 July - 1 Aug 2003, Kathmandu.

Pp.252-264. http://sites.google.com/site/jafgaubase/publication/book-editorial-1

Joshi, BK. 2003a. Hybrid vigor in crosses of IR58025A with Nepalese rice cultivars. SARC Journal of Agriculture 1:167-172.

Joshi, BK. 2003b. Correlation and path coefficient analyses of yield and yield components in $F_{1}$ hybrids rice and their parents. Bangladesh J. Agric. Res. 28(4): 533-540. http://sites.google.com/site/jafgaubase/publication/journal-1

Joshi, BK. 2006. Crossing frequency and ancestors used in developing Nepalese mid and high hill rice cultivars: Possible criteria for yield improvement and rice genes conservation. In: Proceedings of $4^{\text {th }}$ National Conference on Science and Technology, 23-26 March 2004, Kathmandu, NAST. Vol I. Pp.502-513. http://sites.google.com/site/jafgaubase/publication/proceedings-1

Mallick, RN. 1981/82. Rice in Nepal. Kala Prakanshan Kathmandu.

Joshi BK, ML Vaidya, HK Upreti, DR Sharma, CB Rana, PM Mahat, SR Gupta and S Bista. 2014. Rice and buckwheat genetic resources in Karnali zone. Agric. Dev. J. 10:1-22.

Joshi, BK; R Gardner; and DR Panthee. 2011. GGE biplot analysis of tomato $\mathrm{F}_{1}$ hybrids evaluated across years for marketable fruit yield. Journal of Crop Improvement 25:488-496. http://dx.doi.org/10.1080/15427528.2011.587138

Joshi, BK and K Okuno. 2010. A genotype by trait biplot analysis for multiple traits-based selection of genotypes of Tartary buckwheat. Fagopyrum 27:13-19. 
Yan, W and NA Tinker. 2006.Biplot analysis of multi-environment trial data: Principles and applications. Can. J. Plant Sci. 86:623-645.

Shafii, B; KA Mahler' WJ Price; and DL Auld. 1992. Genotype $\times$ environment interaction effects on winter rapeseed yield and oil content. Crop Sci. 32:922-927.

Yan, W; MS Kang; B Ma; S Woods; and PL Cornelius. 2007. GGE biplot vs. AMMI analysis of genotype by environment data. Crop Sci. 47:643-655.

Zobel, RW; MJ Wright; and HG Gauch. 1988. Statistical analysis of a yield trial.Agron. J . 80:388-393. 